\title{
Drug Accountability Group Identifier
}

National Cancer Institute

\section{Source}

National Cancer Institute. Drug Accountability Group Identifier. NCI Thesaurus. Code C87871.

A character or string that represents a drug accountability group. 